\section{Metal Clusters in a New Mixed Halide of Molybdenum (IV) and (V)}

SINCE 1963 there have been several reports of the existence of trimeric clusters of rhenium atoms in anionic and uncharged halogen compounds of rhenium (III) ${ }^{1-5}$. Recently, Dr. R. Colton and Prof, R. L. Martin have adduced magnetic and spectral evidence for the existence of trinuclear clusters in rhenium (IV) chloride ${ }^{6}$ and also in molybdenum (III) chloride? . In an investigation of the reactions of molybdenum hexafluoride as outlined in the following paragraph, a new mixed halide of molybdenum has been isolated and characterized. Magnetic, spectral and conductance measurements indicate that this compound is ionic and contains the $\left(\mathrm{Mo}^{\mathrm{IV}} \mathrm{Cl}_{9}\right)^{3}+$ cation, an entity which fits very well into the scheme proposed by Colton and Martin for stable clusters in molybdenum-chlorine compounds.

When molybdenum hexafluoride reacts at room temperature with chlorides such as phosphorus trichloride, carbon tetrachloride and silicon tetrachloride, the corresponding fluorides $\left(\mathrm{PF}_{3}, \mathrm{CF}_{4}\right.$ and $\left.\mathrm{SiF}_{4}\right)$ are identified among the products of reaction. However, in each of these cases and in many similar reactions ${ }^{8}$ the product containing molybdenum was found to have the empirical formula $\mathrm{Mo}_{2} \mathrm{Cl}_{3} \mathrm{~F}_{8}$. This same orange compound, together with chlorine, is obtained as a result of mixingmolybdenum hexafluoride and molybdenum pentachloride. When hydrogen fluoride was distilled on to molybdenum pentachloride, the same mixed halide was the only involatile product while hydrogen chloride and chlorine could be distilled from the reaction system.

Obviously this mixed halide of odd oxidation state is a compound of considerable stability. It appeared to sublime unchanged at $80^{\circ} \mathrm{C}$, but on further heating it decomposed to molybdenum trichloride and molybdenum hexafluoride. It was found to react with water and with nitrobenzene, and to be virtually insoluble in carbon tetrachloride, in perfluoroheptane and in trifluoroacetic acid. However, it was readily soluble in acetonitrile.

The empirical formula suggested two possible structures. The first of these is a bridged structure with two molybdenum atoms, each surrounded by an octahedron of three chlorine atoms and three fluorine atoms. The two octahedra could share a face containing three chlorine atoms.

This type of structure has been reported for the $\mathrm{W}_{2} \mathrm{Cl}_{9}{ }^{3-}$ anion ${ }^{9}$. An alternative formulation would be an ionic one, for cxample $\left.\left(\mathrm{Mo} \mathrm{Cl}_{3}\right)^{+}\left(\mathrm{MoF}_{6}\right)^{\mathrm{V}}\right)^{-}$. The hoxafluoro molybdate (V) anion is well known, but the $\mathrm{MoCl}_{3}{ }^{+}$cation has not been previously reported.

Conductance measurements in acetonitrile favoured an ionic structure. A value of $80 \mathrm{ohm}^{-1} \mathrm{~cm}^{2}$ was obtained for the molar conductance at a concentration of $4.35 \times$ $10^{-8} \mathrm{M}$ based on the empirical formula $\mathrm{Mo}_{2} \mathrm{Cl}_{3} \mathrm{~F}_{6}$. Flectrolysis of the brown solution in acetonitrile in a threecompartment cell resulted in a brown catholyte solution which gave a positive test for chloride and a negative test for fluoride, and a colourless anolyte which gave a positive fluoride test and a very weak chloride test. This observation was consistent with electrolysis of a compound containing the $\mathrm{MoF}_{6}-$ anion and a cation containing molybdenum and ehlorine.

Detormination of the magnetic susceptibility over the temperature range $93^{\circ}-290^{\circ} \mathrm{K}$ showed it to follow a Curie-Weiss plot with a value for $\theta$ of $155^{\circ}$, which is of the same magnitude as the values found for other compounds containing the $\mathrm{MoF}_{\mathrm{s}}-$ anion ${ }^{10}$. Using this correction, values for the magnetic moment of $1 \cdot 67-1.73$ Bohr magnetons (B.M.) per molybdenum atom were obtained over the temperature range studied. Solution measurements in acetonitrile also gave a value of 1.67 B.M. However, the formulation $\left(\mathrm{Mu}^{\mathrm{IV}} \mathrm{Cl}_{3}\right)^{+}\left(\mathrm{MoF}_{6}\right)^{-}$is at variance with these magnetic data. If 'spin-only' values are assumed for the $d^{1}\left(\mathbf{M}_{\mathbf{o}}^{\mathrm{V}}\right)$ and $d^{2}\left(\mathbf{M}_{\mathbf{0}}^{\mathrm{IV}}\right)$ configurations a value of 2.45 B.M. is obtained. Experimental figures can be reconciled with calculated values, however, if the suggestion is made that the cation is trimeric. The compound could then be formulated $\left(\mathrm{M}_{3}^{\mathrm{IV}} \mathrm{Cl}_{9}\right)^{3+}$ $\left(\mathrm{MO}_{\mathrm{O}}^{\mathrm{V}} \mathrm{F}_{\mathrm{H}}\right)_{3}$

We assumo here that the core of the $\left(\mathrm{Mo}_{3} \mathrm{Cl}_{8}\right)^{3+}$ eation is similar to that found in the $\mathrm{Re}_{3} \mathrm{Cl}_{12}{ }^{{ }^{3-}}$ and $\mathrm{Re}_{3} \mathrm{Cl}_{9}$ structures ${ }^{1-4}$. In this case the molecular orbital treatment ${ }^{6}$ leads to a ground-state electronic configuration $\left(a_{1}{ }^{\prime}\right)^{2}$ $\left(a_{2}{ }^{\prime \prime}\right)^{2}\left(e^{\prime}\right)^{2}$ with two unpaired electrons per trimor. This structure would be expected to give a moment of 1.64 B.M. per molybdenum atom, a value corresponding with two-thirds of an electron per molybdenum atom.

However, the magnetic moment of the anion cannot be neglected. It is assumed here that it contributes one unpaired electron per $\mathrm{MoF}_{b}{ }^{-}$anion to the measured mom. ent. The magnetic moment calculated for tho overall formulation $\left(\mathrm{Mo}_{3} \mathrm{Cl}_{9}\right)^{3+}\left(\mathrm{MoF}_{8}{ }^{-}\right)_{3}$ then becomes I-68 B.M. per molybdenum atom, a value in excellent agreement with the experimental one.

Examination of the spectrum of the compound in acetonitrile shows the presence of a peak in the infra-red region at $630 \mathrm{~cm}^{-1}$. In spectra of mulls and disks absorption at $623 \mathrm{~cm}^{-1}$ has been reported ${ }^{11}$ as being characteristic of the hexafluoromolybdate (V) anion in the well characterized compound $\mathrm{KMoF}_{\mathrm{f}}$.

An acotonitrile solution of the compound shows absorption maxima at $21,500 \mathrm{~cm}^{-1}$ and $14,100 \mathrm{~cm}^{-1}$. The colourless $\mathrm{MoF}_{8}^{-}$anion does not absorb appreciably in the visible region and the observed absorption bands are therefore attributed to the trimeric cation $\mathbf{M o}_{3} \mathrm{Cl}_{9}{ }^{3+}$. The spectra of some related trimeric transition metal chloride clusters are summarized in Table 1 and it is a striking feature that they all show two similar bands.

\section{Table 1. Spectra of Some Chloride Clusters}

\begin{tabular}{|c|c|c|c|c|}
\hline $\begin{array}{l}\text { Com- } \\
\text { pound }\end{array}$ & $\begin{array}{l}\text { Electron } \\
\text { configit- } \\
\text { ration. }\end{array}$ & $\begin{array}{l}\text { Positions of absorption } \\
\text { maxima } \mathrm{cm}^{-1}\left(\varepsilon_{\max }\right)\end{array}$ & Solvent & Referen \\
\hline $\begin{array}{l}\mathrm{Re}_{3} \mathrm{Cl}_{8} \\
\mathrm{Mo}_{3} \mathrm{Cl}_{8}\end{array}$ & $\begin{array}{l}d^{4} \\
d^{3}\end{array}$ & $\begin{array}{l}13,300(410) ; 19,400(1,610) \\
13,150 ; 19,100\end{array}$ & $\begin{array}{l}\text { Acetone } \\
\text { Reflectanco }\end{array}$ & $\begin{array}{l}4 \\
7\end{array}$ \\
\hline $\mathrm{Mo}_{3} \mathrm{Cl}_{6}{ }^{3+}$ & $d^{2}$ & $14,100(160) ; 21,500(1,550)$ & Acetonitrile & This re \\
\hline & $d^{*}$ & 13,$330 ; 22,200$ & Acetonitrile & 12 \\
\hline $\mathrm{r}_{3} \mathrm{C}$ & $d^{1}$ & 13,$100 ; 22,200$ & Acetonitrlle & 12 \\
\hline
\end{tabular}

Conductance measuremonts and electrolysis in acetonitrile suggest that the compound reported here is ionic and its insolubility in non-polar solvents further supports this. Spectra and magnetic measurements suggest a structure based on a trimeric cation and the $\mathrm{MoF}_{6}^{-}$anion. It should be noted that if the molar conductance is calculated on the basis of the formula $\left(\mathrm{Mo}_{3} \mathrm{Cl}_{9}{ }^{8+}\right)\left(\mathrm{MoF}_{6}{ }^{-}\right)_{3}$ a value of $240 \mathrm{ohm}^{-1} \mathrm{~cm}^{2}$ is obtained for the molar conductance at a concentration of $1.45 \times 10^{-3} \mathrm{M}$. Measurement of the molar conductance as the solution is diluted indicates a limiting value of about $330 \mathrm{ohm}^{-1} \mathrm{~cm}^{2}$.

We thank Prof. R. L. Martin and Dr. R. Colton for helpful discussion.

\section{F. STEWART}

T. A. O'DONNELL

Department of Inorganic Chemistry, University of Melbourno, Victoria.

Tobinson, W. T., Fergusson, J. F., and Penfold, B. R., Proc, Chem. Snc. 116 (1963).

${ }^{2}$ Bertrand, J. A., Cotton, F. A., and Dullase, W. A., J. Amer, Chem. Soc. 85, 1349 (1963)

sertrand, J. A., Cotton, F. A., and Dollase, W. A., Inorg. Chem., 2, 1166 (1969).

${ }^{4}$ Cotton, F. A., and Mague, J. T., Inorg. Chem., 3, 1402 (1964),

5 Cotton, F. A., and Lippard, S. T., J. Amer. Chem. Soc., 86, 4497 (1964).

- Colton, R., and Martin, R. L.. Nature, 205, 239 (1965).

7 Colton, R., and Martin, R. L., Nature, 207, 141 (1965).

${ }^{8} 0$ 'Donnell, T. A., and Stewart, D. F. (to be published),

- Brosset, C., Nature, 135, 874 (1935).

${ }^{10}$ Hargreaves, G. B., and Peacock, R. D., J. Chem. Soc., 3777 (1958).

${ }^{11}$ Peacock, R. D., and Sharp, D. W. A., J. Chem. Soc., 2762 (1959).

${ }_{12}$ Colton, $\mathbf{R}$., Rufiñ, R. E., and Tomkins, $\overrightarrow{1}, B$. (to be published). 